\title{
Love, Rights, and Solidarity: Sports' Potential for Recognition
}
Authors' contribution:
A) conception and design of the study
B) acquisition of data
C) analysis and interpretation of data
D) manuscript preparation
E) obtaining funding

\author{
Wivi Andersen \\ The Norwegian School of Sport Science, Norway
}

ABSTRACT

Sport occupies a central role in modern society. Philosophers of sport suggest that sport can offer a realm of play by being structurally and logically independent from everyday life. But what ethical values can sport be seen to offer us, if any? Explanations are sought based on Honneth's theory of recognition. Honneth views the presence of three forms of recognition - love, rights, and solidarity - as necessary conditions not only for a just society, but also for a society in which human beings can realize their potential and experience life as being good. Based on Honneth, I argue that sport can be seen as an arena with potential for an aggregated form of recognition. If practiced in the right way, sport has the potential to realize all three forms of recognition inherent in society.

KEYWORDS normative social theory, Honneth, recognition in sport

\section{Introduction}

Sport in many forms and at many levels seems to attract interest in societies all over the world. Elite sport is broadcasted and viewed by millions, and regular exercise is an important part of many people's lives. Further, sport is integrated in educational systems and schools. How can we understand this extensive fascination with sport? What can sport offer us?

In this essay I will discuss sport in its organized forms, which is training and competition in traditional sport disciplines. These are extensive practices engaging large parts of the population in modern society both as practitioners and as spectators. Thus, the social and cultural impact of sport should not be underestimated. In The White Paper on Sport presented by the Commission of the European Communities (2007), it is stated that a sport "generates important values such as team spirit, solidarity, tolerance and fair play, contributing to personal development and fulfilment". This quote indicates the general view that sport can offer significant values to practitioners.

The values and functions of sport is a recurrent theme in more critical approaches in sport science and research. In his historical study, Allen Guttmann finds modern sports characterized by equality (both in the opportunity to compete and in creating a level playing field), rationalization, specialization, bureaucratization, quantification, and a quest for records (1978). Therefore, in many ways sport mirror the societies of which it is a part, and modern sport are a part of modernity (Guttmann, 1978; Morgan, 1994). 
But the features of modern sport also open a space partially outside the everyday sphere that "holds forth the possibility of a realm of relative if not absolute freedom" (Guttmann, 1978, p. 157).

Within a philosophical and ethical context, the focus is on which potential values we can attain from sport. The essential questions in this article are therefore whether there are certain values in sport, and, if so, under what conditions these values can be expressed.

An ethical view of sport need not be established in opposition to historical or sociological views, but can be developed with history and sociology as important sources. Sports philosophers such as Weiss (1969), Fraleigh (1975), Loland (2002), Morgan (2006), and McNamee (2008) have examined the value of sport to the individual and society. It nevertheless seems that Axel Honneth's theory of recognition has something to bring to the table. It represents aninterdisciplinary approach, but also includes a uniquely ethical perspective of relevance to sport. One advantage of Honneth's work compared to many other philosophical theories is that he seeks to anchor his theory in everyday moral experience, making the application of the theorynot just an overriding analysis, but an attempt to identify moral problems as empirical facts.

\section{Axel Honneth and the theory of recognition}

Honneth's main focus is on social theory and moral philosophy. He seeks to give a "better account of the relationship between socialization and individualization, between social reproduction and the formation of individual identity" (Honneth, 2012, p. 7). His aim is to give an alternative and fruitful account of how human beings develop into moral subjects and agents.

[An account] requires a model of human agency as constituted in and through relations with others, where one's formation as an ethical subject and agent is dependent on the responsiveness of others with respect to care for one's needs and emotions, respect for one's moral and legal dignity, and esteem for one's social achievement (Brink, \& Owen, 2007, p. 4).

If human beings do not experience responsiveness in these areas, they are unable to develop a sound "practical relation-to-self" - a stable personal identity (Honneth, 1995b, p. 129). In order to become a responsible moral agent, one has to experience recognition on three different levels. We need to experience love in our close relationships in order to form self-confidence, rights as a citizen in order to develop selfrespect, and solidarity as a member of civil society in order to form self-esteem (Brink, \& Owen, 2007). Recognition is received through both bodily and verbal communication and is therefore inherent in those reciprocal and social relationships of which we are a part. Recognition can be understood "as a way of rationally responding to evaluative qualities we have learned to perceive in others" (Honneth, 2012, p. 85).

Recognition is fundamental both for the self-realization of individuals and for maintaining a just society. Drawing on Kant's thoughts on self-restriction, Honneth thinks that it is the recognition of essentially human characteristics in the other person that leads us to restrict our action towards others. His theory is an attempt to reconstruct Hegel's concept of recognition, where Hegel saw recognition as "the reciprocal limitation of one's own, egocentric desires for the benefit of the other" (Honneth, 2012, p. 17).

The identification of the three forms of recognition - love, rights, and solidarity - is accomplished through a negative process because morality (or forms of mutual recognition) is made visible and pronounced to us when it is violated. The development of democratic societies can be viewed as a "struggle for recognition" (Honneth, 1995b) ${ }^{1}$, emphasizing that the democratic and humanistic ideals in these societies have been achieved through an ongoing process.

Unlike all utilitarian models of explanation, it suggests the view that motives for social resistance and rebellion are formed in the context of moral experiences stemming from the violation of deeply rooted expectations regarding recognition (Honneth, 1995b, p. 163).

\footnotetext{
${ }^{1}$ My presentation of the theory of recognition in this article is mainly based on Honneth's two works from 1995: The Struggle for Recognition: The Moral Grammar of Social Conflicts (1995a) and The Fragmented World of the Social: Essays in Social and Political Philosophy (1995b).
} 
By viewing the process as a struggle, disrespect becomes an indicator of morally problematic treatment of human beings. As participants in society, we have legitimate normative expectations to receive love, rights, and solidarity. The different forms of recognition are contained within different spheres of society, thereby creating "patterns of recognition" that are typical for each sphere (Honneth, 1995b, p. 95). These patterns of recognition contain a specific potential for moral development and for developing a certain relation to self. The spheres also define the roles the subject is expected to fulfill as a participant in society.

Table 1. Honneth's conceptual framework

\begin{tabular}{cccccc}
\hline Recognition & Self-Relation & Sphere & Role & Violation/Disrespect & Integrity \\
\hline Love & Basic self-confidence & Private & Privateperson & Abuse/harm & Physical integrity \\
Rights & Self-respect & State/Society & Citizen & Denial of rights & Respect \\
Solidarity & Self-esteem & Civil society & Fellow citizen & $\begin{array}{c}\text { Marginalization, } \\
\text { insult }\end{array}$ & Social esteem \\
\hline
\end{tabular}

Source: own studybased on Lysaker $(2011)^{2}$.

There are three forms of disrespect. The differences between these forms are the potential they have for disturbing the individual's development of a sound relationship to themselves and to other persons. The identification of the three forms of non-recognition or disrespect is therefore the key to identifying and understanding the three forms of mutual recognition - love, rights, and solidarity (Honneth, 1995b). Every form of recognition not only establishes a connection to the society, but also enables the person to form certain relations to self.

The most fundamental type of disrespect is that of an individual's physical integrity (Honneth, 1995b). The violation consists not only in the pain experienced, but also in depriving the person of control over his or her own body. Disrespect of physical integrity can strip persons of both self-confidence and trust, and this can affect their interaction with other people. This form of abuse is fundamental. It does not just affect a person's normative understanding of self (as with the other two categories), but can lead to the disruption of or inability to form a positive image of him- or herself even on a physical level. The corresponding form of recognition is love. Love is by nature restricted to a limited number of people, for example, children, lovers, parents, or friends. Therefore, love is tied to our primary social relationships (Honneth, 1995b).

The second type of disrespect is when a person is denied rights within a society. Being denied rights therefore not only involves the exclusion from the sphere of law, but also entails a loss of self-respect in the inability to view oneself as an individual deemed morally competent enough for the reception of the same rights as other members of society. Recognition in the form of rights is distributed within the state, and rights can therefore be viewed as the institutionalized form of respect (Honneth, 1995a, 1995b).

The third type of disrespect is in the sphere of civil society, where disrespect shows in the form of the devaluation or marginalization of individual or collective lifestyles. Honneth views social status as an expression of the degree to which an individual's personal skills and abilities are socially accepted within society (Honneth, 1995a). It is a sign of the value that is ascribed to a person's form of selfrealization. The devaluation of an individual's lifestyle means that individuals cannot accord social value to their abilities. A lack of social esteem for one's traits and abilities therefore causes a loss of self-esteem. The form of recognition corresponding to marginalization is solidarity, something which entails a consciousness of commonly-shared burdens and responsibilities: a shared horizon of values.

${ }^{2}$ Lysaker, Odin (2011). "Axel Honneths anerkjennelsesteori” /“Axel Honneth's theory of recognition"/ (own translation). Lectures, $\mathrm{PhD}$ course, University of Agder, Norway. Used with the author's permission. I have based my table on Lysaker's, but with slight modifications in line with Honneth's more expansive table in The Struggle for Recognition (1995, p. 129). 


\section{Honneth and sport}

Honneth's theory of recognition has not been applied in a larger scale in analyses of sport. A Kantian version of the concept of recognition is presented by Tuxill and Wigmore (1998) in their article "Merely meat'? Respect for persons in sport and games". In it, they present two different versions of the notion of respect: "recognition respect" and "appraisal". The former is based on Kantian analysis and is restricted to intellectual and rational capacities. Tuxhill and Wigmore explore the different ways in which persons can be seen as beings who demand respect, which human features trigger this demand, and whether respect in any of the versions is manifested through sport (1998). Their conclusion is that sport designed so that the maintenance of only a minimum amount of respect for other subjects is perhaps all we can hope for (Tuxill, \& Wigmore, 1998, p. 115). Honneth bases his theory of recognition on Hegel, although his notion of respect has a "strong Kantian element" (Anderson, 1995, p. 14), and despite Tuxhill and Wigmore's conclusion, it seems that Honneth's approach allows for a greater moral potential in sports than that of a minimum demand.

Honneth's theory is developed within the perspective of a democratic nation-state. Sport can be viewed as an arena for the recognition of athletic skills, thereby placing itself within the area of recognition that Honneth refers to as "solidarity". Honneth focuses largely on working life when discussing solidarity, but his definition of the arena of solidarity as practiced with a shared value-horizon opens for most cultural activities as well. To satisfy Honneth's criteria for ethical legitimacy, sport cannot be an arena for marginalization or insult. This is a normative minimum demand, but I propose that sport might have the potential for particularly strong recognition or an aggregated form of recognition in which all three forms of recognition can be given. If love, solidarity, and rights can be identified as essential features of sport, the practice is more than morally acceptable.

A prerequisite seems to be that sport is a sphere partially located outside everyday life. Based on Suits (1988, 1973), and Morgan (1994, 2006), I suggest that sport is demarcated from society in general by their game rules and inner logic, thereby creating a sphere set apart - at least partially - from our everyday life. After stating the case for sport as a separate sphere, I proceed to discuss whether there are certain values in sport. Within Honneth's theory these values should be forms of love, rights, and solidarity. I will also discuss under what conditions these values can be expressed.

\section{Sport as a separate sphere}

In line with Guttmann (1978), the idea of sport as a separate sphere of society has also been a prevailing argument within the philosophy of sport. In his classic article "The Elements of Sport", Bernard Suits (1988, p. 11) defines sports as a subgroup of games and offers a definition of what it means to participate in a game: "Playing a game is the voluntary attempt to overcome unnecessary obstacles". To Suits, this willingness expresses a playful attitude-the participant has to accept the irrationality of game rules that in effect sets the game apart from everyday life. If participating in the 3000 meter steeple chase, for example, one has to accept the necessity of jumping over the obstacles instead of taking the easiest way to the finishing line. Sport is distinguished from everyday instrumental rationality and creates a space containing the play/game/sport's own logic - sport's ludic element. The conditions for establishing this separate play-sphere are created by the rules of the game and the players' acceptance of these rules. This is in line with Morgan's argument on the inner logic of sport (1994). According to Morgan (1994, p. 216), the irreducibility of this inner logic "disconnects sporting practices from whatever obvious links they might have to society and to the rest of our lives and molds them into novel, distinctive undertakings".

The link between play, games, and sport has been discussed by many sports philosophers and historians. Guttmann (1978), Suits (1973), Morgan (1994), Loland (2002), and others have stressed the connection between sport and play. Guttmann $(1978$, p. 7) defines sports as "playful" physical contests, that is, as non-utilitarian contests which include an important measure of physical as well as intellectual skill. Suits (1988) claims that all games, including sports, have much in common with play because they 
all require a playful attitude to accept irrational rules. Morgan (1994, p. 211) describes the "gratuitous logic" of sport as the delight in overcoming the complex and indirect ways to achieve the goal of the game constituted by the game rules. Loland's theory of fair play (2002) maintains that sports competitions are at their best when performed with a playful attitude. The potential for play can therefore seem to be inherent in sport, but this potential is not always realized.

An early and influential cultural theory of play was presented by Johan Huizinga in Homo Ludens (Huizinga, 1963). Huizinga sees play as the foundation for all other forms of cultural expression and puts play at the center of all surplus human activity. Play in its extensive forms can be seen as establishing arenas for human coexistence and cooperation, or within the framework of a theory of recognition as an arena for intersubjective recognition. Huizinga himself opposed the view of sport as being closely related to play. He saw the competitive sports of the 1930s as being a dichotomy of play, more similar to the industrialized work in the modern Western world than to a leisure activity generating human forms of expression. Nevertheless, in line with Loland's fair play theory (2002), I adopt the view that sport has a non-utilitarian character of play when performed at its best.

The area of play is also discussed by Honneth. By receiving love, our primary needs and emotions are confirmed, and through a positive primary relationship we can develop self-confidence. Honneth draws on the work of psychoanalyst Donald W. Winnicott (1965), who found that the physical contact between child and parent is essential for the child's further development, and when the secession between child and parent is substituted with an area of play, the area of the stress of reality-acceptance is relieved by an "intermediate area of experience" (Winnicott, \& Honneth, 1995b, p. 103).

\section{Applying Honneth}

Honneth's theory conceptualizes recognition in modern democratic societies and should be relevant in an analysis of sport. But it is not only his concepts that seem appropriate for a critical analysis of sport. My initial assertion of the benefits of using the theory was that it is anchored in lived ethical life. It represents an attempt to assess the gap between the ideal and reality. This anchoring in everyday life is made possible by an "empirically grounded phenomenology" (Lysaker, 2008, p. 247). The starting point for analysis is a case - an individual human experience of violation or disrespect - and this is what gives the method the phenomenological input. The case is an indication of a problem that is taken seriously by an individual or a group, but Honneth stresses that these experiences must be further confirmed by empirical scientific research and the phenomenological and empirical input has to be examined critically.

In the argument that follows, I will discuss whether love, rights, and solidarity are present in sport, and, if so, under what conditions they exist. I will do this primarily using the first and last steps of the method (the phenomenological input and critical analysis). The methodical approach is to identify the violation or disrespect inherent in the case, thereafter identifying the lacking form of recognition corresponding to the disrespect. Finally, a critical reflection on the gap between reality and possibility is required to pinpoint if there is a potential of recognition. The realization of any possible potential will depend upon whether the context has the resources to foster and promote the potential for recognition. The use of just the first and last step in Honneth's method represents a danger in that the phenomenological input might risk being unsupported by any empirical knowledge from the social sciences of sport. Nevertheless, it can give an indication of how these forms of recognition are manifested - or should be manifested - within sport. 


\section{Love}

Love is an emotional relationship between significant others, by nature restricted to a limited number of partners in interaction (Honneth, 1995b). It is a condition for developing self-confidence in identifying and voicing needs and desires in a context of trust. How then does this form of recognition apply to sport? I suggest that love can be inherent in sport both as a form of reciprocal recognition between athletes and as play.

\section{Love in sport}

The Norwegian/ Ugandan boxer, Richard Kiwanuka, is a refugee from Uganda who came on his own to Norway when he was 16 years old.His family was killed by rebels, and Kiwanuka was traumatized from his experiences. He started boxing in Bergen Atletklubb and says boxing helped him recover from his traumas. After boxing for just a few months, his appetite came back and he started sleeping soundly again (Stokke, 2013). He also developed friendships through sport. In 1997, he won the featherweight class in the Norwegian junior championship and was awarded the "Best Fighter" title, regardless of weight class. The year after, he won the featherweight class in the National Championship for seniors and gained a place on the national team (Sunnanå, 2013). He started the organizations "Way Forward" in Norway and "Bring Children From Streets" in Uganda, where the focus lies on using sport for gaining self-confidence, giving children the opportunity to experience the mastering of skills. Kiwanuka has received many awards for his work, among them the 2010 "Role Model of the Year" award from the Ministry of Children, Equality, and Social Inclusion. Kiwanuka claims boxing saved his life and that sport makes onestrong and gives one selfconfidence (Stokke, 2013).

The story of Kiwanuka can be interpreted in a way that gives credibility to Honneth's concept of love. Honneth stresses that the disrespect or violation of physical integrity can affect the individual's relationship with other persons and with his/herself. This implies that the person's normative self-relation as well as his/her physical self-relation is affected. Kiwanuka's trauma seemed to make him "lose" himself. Through boxing, he regained confidence in himself - and also in his fellow human beings. It seems that through boxing, Kiwanuka experienced Honneth's intersubjective form of love: a bond between significant others.

The physical side of sport and the physical closeness that one acquires by competing with others can establish a close friendship between athletes. For Honneth, love as the fundamental relationship of recognition is tied to our primary social relationships: family relationships, friendships, and intimate relationships. For many athletes, sport has had a formative role in their relationships, and their participation in sport has allowed them to meet people with whom they have formed a close friendship. For Kiwanuka, sport re-established his ability to form trusting and reciprocal relationships with other people.

But love does not only seem to be present in sport as a form of reciprocal recognition. Kiwanuka's experiences of violation seem to have been overcome by his devotion to boxing. Not only did he regain trust in his fellow human beings, but he claims to have regained a connection to himself and his own body through sport. The paradox is that his reconnection to himself, also on a physical level, occurred through a sport that can seem both violent and aggressive to outsiders. However, in his qualitative studies of boxing, sociologist Wacquant $(1992,2005)$ demonstrates the significant potential of the sport - and that of sparring in particular, which involves a deep interaction and collaboration between boxers - in developing meaning, trust, and friendship. Building on Winnicott's findings, Honneth argues that the child's creativity and human imagination in general presupposes that the child develops an ability to be alone. Through close contact with its parents, the child creates a basic sense of security and trust enabling it to exist in - and create - its own world, a play world. By expressing ourselves through play, we have the chance to recreate this earliest balance between inner and outer reality; we can lose ourselves in play, for a time allowing the mind and body to be experienced as a complete whole. Through play, Kiwanuka seemed to be able to regain an access to himself that was seemingly lost through the violation he had suffered.

Unfortunately, Kiwanuka's experiences of violation and loss are not unique in their character. The story is nevertheless a story of hope and the realization of human potential. As I initially stated, my use 
of Honneth's method in this article is just an onset of the method; illustrating the concepts with a phenomenological experience and further research into the potential of sport in "regaining" oneself following trauma would be interesting. If Kiwanuka's story is supported by psychological and sociological findings, this would then indicate that sport's potential for love is not just as a reaffirmation of past experiences of love, but also perhaps as a compensation for love never given. I suggest that the arena for play created in sport might give a version of love that is less inter-subjective and more self-affirming because it involves the absorption of the whole person. In addition to the play element in games and sports which forms a reconstruction of our first form of self-recognition, sport also offers an arena for being completely absorbed and involved as a phenomenological being. Consequently, there is a potential for "self-recognition" in sport that can be further developed within the theory of recognition.

\section{Rights}

The second type of disrespect is when individuals are structurally excluded from receiving certain rights within a society (Honneth, 1995b). "Rights" are viewed as a pattern of recognition that has developed historically through a struggle for recognition. Traditionally, recognition in the form of rights was closely connected to social status, but the transition to modernity in Western societies entailed a secession of rights from privileges and social status, thereby establishing two new forms of recognition, one general and one individual. The concept and awareness of rights is therefore dependent on the historical and social context (Honneth, 1995b). The recognition of rights is the general form because it entails the recognition of the subject as a generalized being who inhibits the necessary criteria (moral accountability) for participation in society's formation of will, for example by having the right to vote. By receiving rights, individuals are recognized with respect by other rights holders. Receiving respect is important for being able to form self-respect, that is, viewing oneself as equal to others. Solidarity is the individual counterpart of rights; it is the recognition of the individual, while rights are directed toward a universalized and generalized other (Honneth, 1995b).

\section{Rights in sport}

In the early years of ski jumping as an organized sport in Norway, women were participants in the competitions. But female competitors usually had to compete against men since competitions for women were not held at that time. During the $20^{\text {th }}$ century, ski jumping became even more clearly a masculine domain (Vertinsky et al., 2009), and despite the fact that there were some prominent female ski jumpers, women were excluded from the sport. Women jumpers never entered any national team and were marginalized in the sport until the beginning of the 1990s. At that time, women ski jumpers, both in Norway and in the rest of the world, were allowed to be test-runners in international competitions for men. In 2004, a conflict arose between the most prominent female Norwegian jumpers and the Norwegian Ski Association (NSF). The best female jumpers were denied the task of being test-jumpers in the (male) Continental Cup arranged in the ski flying arena in Vikersund, Norway. The NSF stated that the grounds for the rejection were that only a few female jumpers were competent enough to master the ski flying arena and that it would be too dangerous to allow the female jumpers to undertake the test jumps (Kjernli, 2014). There was an extensive media debate on the topic, and the ongoing conflicts between the female jumpers and the NSF were also reported to the Norwegian Equality and Anti-Discrimination Ombudsman, who deemed the exclusion to be discrimination (http://www.ldo.no, 2004).

During the conflict between the NSF and the female jumpers, one of Norway's leading daily newspapers, Verdens Gang, had a web debate where Anette Sagen, the best Norwegian female jumper, answered questions online. When questioned about her qualifications to jump in the ski flying hill of Vikersund and presented with doubts about her skills, Sagen answered: "I am sure. I am qualified" (http://tpn.vg.no/intervju/tittel/87, 2004). 
The conflict between the female ski jumpers and the NSF illustrates how athletes can feel deprived of what they see as a right within their sport. Female ski jumpers were not being recognized as having earned the right (by being skilled ski jumpers and training to a certain level) to test jump ${ }^{3}$. "Rights" within the sphere of sports can be seen as being contingent to physical capacity. In sport, what we want to measure is first and foremost athletic abilities. To be a member of any sports community, it is necessary to possess a certain skill (and the will to develop it). Sagen and the other female jumpers felt they were not being respected as ski jumpers. It could be argued, as the NSF did, that the women lacked the necessary skills to jump the ski flying arena. Such an objection would need to be founded in a safety concern, since safety is a leading principle in ski jumping, thereby reflecting the principle of equality. If women ski jumpers measure up to the standard needed to perform a safe jump, the only reason for excluding them would seem to be to preserve ski jumping for men.

\section{Solidarity}

The form of mutual recognition present in civil society is social esteem or appraisal which allows individuals to relate positively to their personal skills and abilities. The practice of marginalization or insults is the disrespect shown in this area. Honneth (1995b) regards this form of recognition as being important in preserving and expanding a positive relation-to-self. This is the sphere where we are given recognition as individuals.

While rights are appraisals of the traits the subject shares with other members of society, social appraisal is given to the abilities that are particular to the individual, those traits that mark individuality. It presupposes that social relations are characterized by symmetrical appreciation between persons that are both autonomous and individualized (Honneth, 2007). Because it is individual in form, the appreciation of skills and abilities is not available to all. Different skills and abilities are not shared human traits, but contribute to a shared horizon of values within a group or a community (Honneth, 1995b). The more diversified the shared horizon is, the more personal traits and skills will be recognized, and the more room for self-realization/individualization there will be. The potential for recognition in the form of solidarity in a pluralistic society is a "post-conventional" form referring to a situation in which most members of society can be given social appraisal for their skills and abilities and thereby establish and maintain their self-esteem (Honneth, 1995b, p. 124). Social status and respect are no longer bestowed on the individual (mainly) because of their participation in a collective activity, but instead they are given because of personal achievement within a recognized practice. They share certain values that make each person's skills and abilities seem meaningful for their shared practice.

Being valued in this way has an effect on people's practical relationship to themselves. We are being recognized and given recognition for the skills and abilities that we are born with or have developed in life: these are the distinguishing marks of individuals. Recognition and self-realization can be said to express the ultimate expression of individual freedom. In viewing sport as a realm of relative freedom (Guttmann, 1978; Morgan, 1994; Suits, 1988), sport seem to create an arena for this "post-conventional form" of recognition of athletic skill appreciated through the shared value-horizon of sport.

Suits $(1973,1988)$ maintain that this separate sphere of play/ games and sports creates a space for expressing more of ourselves than society normally allows room for. The increasing popularity of modern sports can be interpreted as a change towards according social value to one's athletic skills. Therationalization and bureaucratization of sport can be viewed as a transformation from a pastime to a more organized practice accepted and appreciated by society as a legitimate and acceptable way of spending one's leisure time. The status of sport as a valid and important form of expressing oneself gives sport participants the possibility and potential of recognition in the form of solidarity. Their efforts and priorities are seen as being worthy of achieving social acceptance. This places sport safely within the sphere of civil society in the conceptual framework.

\footnotetext{
${ }^{3}$ The conflict over female ski jumping in Norway was not about women competing in the same class as men, but about
} females being allowed to compete and jump at all. 


\section{Solidarity in sport}

In addition to sport being accepted in society as a chosen lifestyle or leisure activity, I suggest that recognition can be received within sport itself. Following Honneth's method, the negation of recognition must first be identified.

A case that illustrates disrespect in the form of a lack of social acceptance within sport is that of Michelle Dumaresq, a transsexual Canadian downhill mountain biker. Michelle Dumaresq, who became a professional woman mountain biker, was born a man but realized as a child that her gender identity was that of a woman (Duthie, 2004). Suffering from gender dysphoria (a diagnosis of persons with a significant discontent /dysphoria/ with the biological sex they have been assigned to and/ or expectations linked to an associated gender role), Dumaresq started hormone treatment at the age of 21 and underwent sex reassignment surgery in 1996, when she was 26 (Reifner, 2002).

Dumaresq started competing in 1999, always being open about her transgender history. She won the novice class at the Bear Mountain race in British Columbia in 2001, 2.5 seconds faster than the fastest women professionals, and rose through the Canada Cup Mountain Bike Series from beginner to pro during her first year, winning the national series in 2002. But her progress was not to go undisputed, and in July 2001 the Canadian Cycling Association and Union Cycliste Internationale (UCI) suspended Dumaresq's license after a campaign organized by some of Dumaresq's fellow bikers. It was reissued in 2002 due to the fact that she was a woman in legal terms (Billman, 2004). In 2006, Dumaresq won the Canadian Women's Downhill Championship. The winner of second place, Danika Schroeter, donned a shirt that proclaimed "100\% Pure Woman Champ 2006". Schroeter was suspended for three months for this inappropriate behavior (The Vancouver Sun, 2006, August 3). Years later, Dumaresq described the incident as "The Day I Died" (Dumaresq, 2014).

By analyzing cases of disrespect, it is possible to uncover what the term solidarity should entail in sport: the appreciation and recognition of athletes' skills and abilities by their fellow players and/ or competitors. They are seen as a contribution to the shared value-horizon established by sport's inner logic and rationality (Guttmann, 1978; Morgan, 1994). This "inner form" of recognition is inherent within the practice. I suggest it is a stronger form of recognition than the recognition given to athletes in society in general: recognition given by partners that the athlete normally views as being more competent is more significant for the athlete because other athletes possess the same skills and abilities the athlete seeks to manifest. Naturally, any violation or expression of disrespect within the practice might have the power to interrupt an athlete's relationship to him- or herself to a greater degree than "external" recognition.

There may seem to be a striking parallel in the stories of Dumaresq and the Norwegian women ski jumpers in so far as individuals and groups in both cases are excluded or marginalized from a sport because of their gender. But in Dumaresq's case, despite having the formal right to compete, solidarity was not given by her fellow women racers. Dumaresq was not seen as being one of them. The struggle of the Norwegian women jumpers was a struggle for their rights; they thought themselves athletically qualified to jump in the ski flying arena. They fought to be granted rights given to them as "generalized others" - as persons embodying a relevant athletic skill.

\section{Concluding Remarks}

The essential questions in this article asked whether there are certain values in sport, and, if so, under what conditions these values can be expressed. I have given a tentative argument for the relevance of Honneth's theory to an understanding of the value of sport. The conclusion is that sport has the potential of recognition in three different forms: love, solidarity, and rights. This might be true of other practices as well. But it seems to me that sport might have an especially strong potential in this respect. The aggregated recognition within sport is not just in that the three forms can be present, but also that at least two of these forms seem to be double-layered: solidarity (both as society's acceptance of sport as a lifestyle and solidarity between athletes) and love (as in play - a "love relationship" to oneself - and as in friendship between 
athletes). In other words, if practiced according to their ideals of fair play, sport possess significant ethical potential.

Within this perspective, sport can also be seen to offer recognition democratically; it is attainable for many of us and at many different levels of achievement. Not everyone can become a professional athlete or reach positions in society that are subject to significant social recognition, but most of us can achieve a performance level in sport high enough to experience play and "deep flow". Team players and competitors at all levels find recognition in the forms of friendship, solidarity, and rights in terms of receiving their due according to the rules. The democratic potential for recognition in sport is something that should be further explored.

This contention should by no means be understood as a claim that sport realize moral values more or less by necessity. At the outset of this article, I pointed out the seemingly vast distance between sporting ideals and sporting reality. To me, it seems that Honneth's theory of recognition is an answer to Morgan's challenge to critical theory (Morgan, 1994). The theory of recognition contributes to new perspectives on sport not only by articulating its values, but also by identifying violations or disrespect, thereby initiating reform in the form of a struggle for recognition.

\section{Acknowledgements}

I would like to thank Professor Sigmund Loland and Professor Ivan Waddington for helpful comments and insights in developing this paper.

\section{REFERENCES}

Anderson, J. (1995). Translator's Introduction. In A. Honneth (Ed.), The Struggle for Recognition (pp. 10-21). Cambridge: Polity Press.

Billman, J. (2004). Michelle Raises Hell: The Hottest Transgender Talent in Professional Sports is Making the Competition See Pink. Outside Magazine.

Brink, B., \& Owen, D. (2007). Recognition and Power: Axel Honneth and the Tradition of Critical Social Theory. Cambridge: Cambridge University Press.

Dumaresq, M. (2014). The Day I Died. Retrieved from http://transgriot.blogspot.no/2014/06/the-day-i-died.html

Fraleigh, W.P. (1975). Sport-Purpose. Journal of the Philosophy of Sport, 2(1), 74-82.

Guttmann, A. (1978). From Ritual to Record: The Nature of Modern Sports. New York: Columbia University Press.

Honneth, A. (1995a). The Fragmented World of the Social: Essays in Social and Political Philosophy. Albany: State University of New York Press.

Honneth, A. (1995b). The Struggle for Recognition: The Moral Grammar of Social Conflicts (J. Anderson, Trans.). Cambridge: Polity Press.

Honneth, A. (2007). Disrespect: The Normative Foundations of Critical Theory. Cambridge: Polity Press.

Honneth, A. (2012). The I in We. Cambridge: Polity.

Huizinga, J. (1963). Homo Ludens: Om kulturens oprindelse i leg/Homo Ludens: A Study of the Play Element in Culturel. København: Gyldendal.

Kingston, G (2006). Banned for mocking transgendered winner. The Vancouver Sun (2006, August 3). Retrieved 22 June, 2014, from http://www.canada.com/vancouversun/news/story.html?id=b49de62b-e7dc-4699-83ab-ada11000f500

Kjernli, E. (2014). Nekter å gi opp drømmen om skiflyging - 10 år etter krangelen med Yggeseth og FIS /Refuses to give up the dream of ski flying - 10 years after the conflict with Yggeseth and FIS/. Retrieved from http://www.nrk.no/

LDO.no (2004). Skihopp for kvinner /Ski jumping for women/ (2004/049). Retrieved from http://www.ldo.no/no/Klagesaker/Arkiv/Likestillingsombudets-klagesaker/2004/Skihopp-for-kvinner-/

Loland, S. (2002). Fair Play in Sport: A Moral Norm System. London: Routledge.

Lysaker, O. (2008). Sårbarhet og ukrenkelighet: filosofisk-antropologisk innholdsbestemte menneskerettigheter /Vulnerability and inviolability: Philsophical-anthropological determined human rights/. Nordisk tidsskrift for menneskerettigheter /Nordic Journal of Human Rights/, 26(3), 244-258.

McNamee, M.J. (2008). Sports, Virtues and Vices: Morality Plays. London: Routledge. 
Meier, K.V. (1988). Embodiment, Sport and Meaning. In W.J. Morgan, \& K.V. Meier (Eds.), Philosophic Inquiry in Sport (pp. 93-101). Champaigne,Illinois: Human Kinetics Publishers.

Morgan, W.J. (1994). Leftist Theories of Sport: A Critique and Reconstruction. Urbana: University of Illinois Press.

Morgan, W.J. (2006). Why Sports Morally Matter. New York: Routledge.

Reifner, S. (2002). Switching Gears. Sports Illustrated Women, 4.7, 20-22.

Sagen, A.(2004). VG Nett. Retrieved November 20, 2013, from http://tpn.vg.no/intervju/tittel/87

Stokke, O. (2013, June 18). Hvis man er likestilt som ung, blir man det som voksen /If you experience being treated as an equal as a child, you tend to respect equality as an adult/. Aftenposten. Retrieved from http://www.aftenposten.no/nyheter/iriks/Hvis-man-er-likestilt-som-ung_-blir-man-det-som-voksen-7230903.html

Suits, B. (1988). The Elements of Sport. In W.J. Morgan, \& K.V. Meier (Eds.), Philosophic Inquiry in Sport (pp. 93101). Champaign, Illinois: Human Kinetics Publishers.

Sunnanå, L.S. (2013). Tidligere barnesoldat fra Bergen hjelper slumbarn /Former child soldier from Uganda helps children in the slums/. Korrespondentbrevet, NRK. Retrieved from http://www.nrk.no/verden/korrespondentbrevet-16.november-1.11354983

Tuxill, C., \& Wigmore, S. (1998). 'Merely meat'? Respect for persons in sport and games. In M.J. McNamee, \& S.J. Parry (Eds.), Ethics and Sport. London: E \& Fn Spon.

Vertinsky, P., Jette, S., \& Hofmann, A. (2009). "Skierinas" in the Olympics: Gender Justice and Gender Politics at the Local, National and International Level Over the Challenge of Women's Ski Jumping. Olympika, 18, 25-55.

Wacquant, L. (1992). The social logic of boxing in black Chicago: toward a sociology of pugilism. Sociology of Sport Journal, 9(3), 221-254.

Wacquant, L. (2005). Carnal connections: On embodiment, apprenticeship, and membership. Qualitative Sociology, 28(4), 445-474.

Weiss, P. (1969). The Challenge of the Body. Sport: A Philosopic Inquiry (pp. 89-92). Carbondale: Southern Illinois University Press.

White Paper on Sport (2007). The White Paper on Sport. Comission of the European Communities. Retrieved from http://eur-lex.europa.eu/legal-content/EN/TXT/?qid=1389190214279\&uri=CELEX:52007DC0391

Wilson, D. (Producer), \& Duthie, K. (Director) (2004). 100 Percent Woman: The Story of Michelle Dumaresq. Vancouver, BC: Artemis Dreams Production.

AUTHOR'S ADDRESS: $\quad$ Wivi Andersen

Department of Cultural and Social Studies

The Norwegian School of Sport Science

Sognsveien 220

0806 Oslo, Norway

Email: wivi.andersen@nih.no

Received: 29 October 2015; Accepted: 16 November 2015 